\title{
Cranial bone regeneration according to different particle sizes and densities of demineralized dentin matrix in the rabbit model
}

\author{
Jin-Woo Nam, Moon-Young Kim and Se-Jin Han ${ }^{*}$
}

\begin{abstract}
Background: The objective of this study was to place bone graft materials in cranial defects in a rabbit model and compare their bone regenerating ability according to the size and density of demineralized dentin matrix (DDM).

Methods: We selected nine healthy male rabbits that were raised under the same conditions and that weighed about $3 \mathrm{~kg}$. Two circular defects $8 \mathrm{~mm}$ in diameter were created in each side of the cranium. The defects were grafted with DDM using four different particle sizes and densities: $0.1 \mathrm{~mL}$ of $0.25-$ to $1.0-\mathrm{mm}$ particles (group 1); 0 . $2 \mathrm{~mL}$ of 0.25 - to 1.0-mm particles (group 2); $0.1 \mathrm{~mL}$ of 1.0- to 2.0-mm particles (group 3); and $0.2 \mathrm{~mL}$ of 1.0- to 2. 0-mm particles (group 4). After 2, 4, and 8 weeks, the rabbits were sacrificed, and bone samples were evaluated by means of histologic, histomorphometric, and quantitative RT-PCR analysis.
\end{abstract}

Results: In group 1, osteoblast activity and bone formation were greater than in the other three groups on histological examination. In groups 2, 3, and 4, dense connective tissue was seen around original bone even after 8 weeks. Histomorphometric analysis of representative sections in group 1 showed a higher rate of new bone formation, but the difference from the other groups was not statistically significant. RT-PCR analysis indicated a correlation between bone formation and protein (osteonectin and osteopontin) expression.

Conclusions: DDM with a space between particles of $200 \mu \mathrm{m}$ was effective in bone formation, suggesting that materials with a small particle size could reasonably be used for bone grafting.

Keywords: Demineralized dentin matrix, Bone regeneration, Osteoinduction, Particle size

\section{Background}

Recently, dental implants have been used to restore defects in patients who are partially or completely edentulous. The proper placement of implants and adequate bone are necessary for long-term stability and sufficient functionality. In the past, dental implantation was possible under only limited circumstances; however, with improvements in the implant itself, as well as in clinical techniques, bone grafting now enables bone to form even when it is deficient, increasing the rate of success.

Bone graft materials can be classified based on their origin, that is, autogenic, allogenic, xenogenic, and alloplastic

\footnotetext{
* Correspondence: hanimplant@dankook.ac.kr

Department of Oral and Maxillofacial Surgery, College of Dentistry, Dankook University, 119 Dandae-ro, Dongnam-gu, Cheonan, Chungnam, South Korea
}

[1]. Of these, autogenic bone is considered to be the ideal material, although it is limited in terms of its availability, the need for additional surgery, and complications [2-5]. Therefore, allogenic, xenogenic, and alloplastic types of the bone are used more often, even though allogenic and xenogenic bone are associated with such problems as immune reactions and infection, and alloplastic bone provides merely a frame for bone formation [6-10].

The bone component from the extracted teeth is now being used as bone graft material and comprises $55 \%$ minerals and $45 \%$ organic substances [11]. The minerals mainly consist of low-crystalline hydroxyapatite and betatricalcium phosphate $(\beta-\mathrm{TCP})$, and the organic substances are non-collagenous protein, type I collagen, and bone morphogenetic proteins (BMP) [12]. Because this material 
is derived from autogenic tissue and is therefore biocompatible, there is no risk of immune reaction, rejection, or disease transmission. In addition, osteoconductivity and osteoinductivity can be expected, and autogenic bone can also be formed in a variety of sizes and shapes [13, 14].

Meanwhile, researchers have attempted to improve the success rate of bone grafting. Bone regeneration involves many variables, including size, type, and handling of the bone graft material; the conformation of the bone defect; and whether or not a membrane is applied. In addition, bone graft materials must have a three-dimensional structure that is similar to that found in vivo, must maximize the attachment and functional role of cells, and have the proper strength [15]. Their porous structure acts as a pathway to allow body fluids, blood vessels, and cells to penetrate the material easily. It must also have sufficient surface roughness to permit the osteoblasts to attach easily and proliferate and must provide space for nutrients. In addition, it helps to combine and restore effective factors in order to form satisfactory bony tissue. A large surface area also maximizes contact with body fluids. Wettability, or the degree to which a liquid can spread over a large surface area, provides an optimal environment for the growth of a new bone and the ability to continue to form the new bone over the long term.

Several researchers have reported that the particle size of bone graft materials plays a key role in activating osteoconduction and affects the quality of the new bone [16-19]. Robinson et al. stated that materials with a small particle size enhance bone formation and accelerate bone resorption and remodeling [20]. Rivault et al. reported that particles in autogenic bone, which are $100 \mu \mathrm{m}$, help activate osteoblasts [21]. Shapoff et al. reported that the optimum particle size would be 100 to $300 \mu \mathrm{m}$ [22]. Pallesen et al. stated that particles 0.5 to $2.0 \mathrm{~mm}$ in size were preferable to those measuring $10 \mathrm{~mm}$ because they allowed more rapid bone remodeling [23]. However, Hall et al. reported that the size was not significant, and Fucini et al. noted that results did not differ significantly when particles 250 to $500 \mu \mathrm{m}$ or 850 to $1000 \mu \mathrm{m}$ were used [24, 25]. Using demineralized, freeze-dried bone in a rabbit model, Urist et al. reported that particles 250 to $420 \mu \mathrm{m}$ in size interrupted chondrogenesis and ossification, whereas those 1000 to $2000 \mu \mathrm{m}$ in size were more effective [26]. Although all these researchers showed that the amount of bone formed appeared to be influenced by the particle size of bone graft materials, their findings are still controversial.

An adequate size that permits bone formation on the porous structure of bone graft materials is reported to be about $150 \mu \mathrm{m}$, which is the size of the gaps in cancellous bone. Demineralized dentin matrix (DDM) is a favorable material for bone formation because it contains osteoconductive material and has dentinal tubules 1.2 to $2.5 \mu \mathrm{m}$ in diameter $[27,28]$. Moreover, both its porous structure and the space between the materials enhance bone formation.

Our objective in this study was to compare the boneregenerating ability of DDM as bone graft material by placing it in cranial defects of rabbits using different sizes and densities of this material.

\section{Methods}

\section{Animal models}

The experimental animals included nine healthy male rabbits, which weighed around $3 \mathrm{~kg}$ and were raised for a specified period of time under the same conditions. After we had ensured that they had no natural abnormalities over 7 days of their adjustment, the animals were approved for the experiment. The animals were raised in an average room temperature of $22{ }^{\circ} \mathrm{C}$, with a 12-h cycle of light and shade and water and solid food freely available. Animal selection and management, surgical protocol, and preparation followed routines were approved by the Institutional Animal Care and Use Committee at Dankook University, Cheonan, Korea.

\section{Preparation of human DDM}

The teeth extracted from humans were preserved in $70 \%$ ethyl alcohol and shipped to the Korea Tooth Bank (Seoul, Korea), where foreign materials attached to the teeth such as soft tissues or dental calculi were removed. The teeth were then separated into a crown part and a root part, each going through a grinding process to produce particles that were 0.25 to $1.0 \mathrm{~mm}$ in size or 1.0 to $2.0 \mathrm{~mm}$ in size. These crushed particles were put into a solution of distilled water and hydrogen peroxide, and any foreign materials that remained attached to the particles were removed by means of an ultrasonic cleaner. Cleaned particles were dehydrated with ethyl alcohol and were defatted using an ethyl ether solution. The material was then demineralized for $15 \mathrm{~h}$ in hydrochloric acid, washed for $120 \mathrm{~min}$ in Tris-hydrochloric acid, and freeze-dried. After these processes had been completed, the particles went through lyophilization and disinfection with ethylene oxide gas and were transported in a covered state to the laboratory and used for transplantation (Fig. 1).

\section{Surgical procedure}

Ketamine HCL (Ketara, Yuhan, Seoul, Korea) 10 mg/kg and xylazine (Rompun, Bayer Korea, Seoul, Korea) $0.15 \mathrm{mg} / \mathrm{kg}$ were injected into the rabbit muscle to induce anesthesia, and $2 \%$ lidocaine with 1:100,000 epinephrine was injected at the surgical site for hemostasis; gentamicin sulfate (Dongwha Pharm, Seoul, Korea) $2 \mathrm{~mL}$ was injected prior to surgery to prevent infections.

An incision was made along the midline of the skull to expose the suture area. Periosteum was elevated to the 


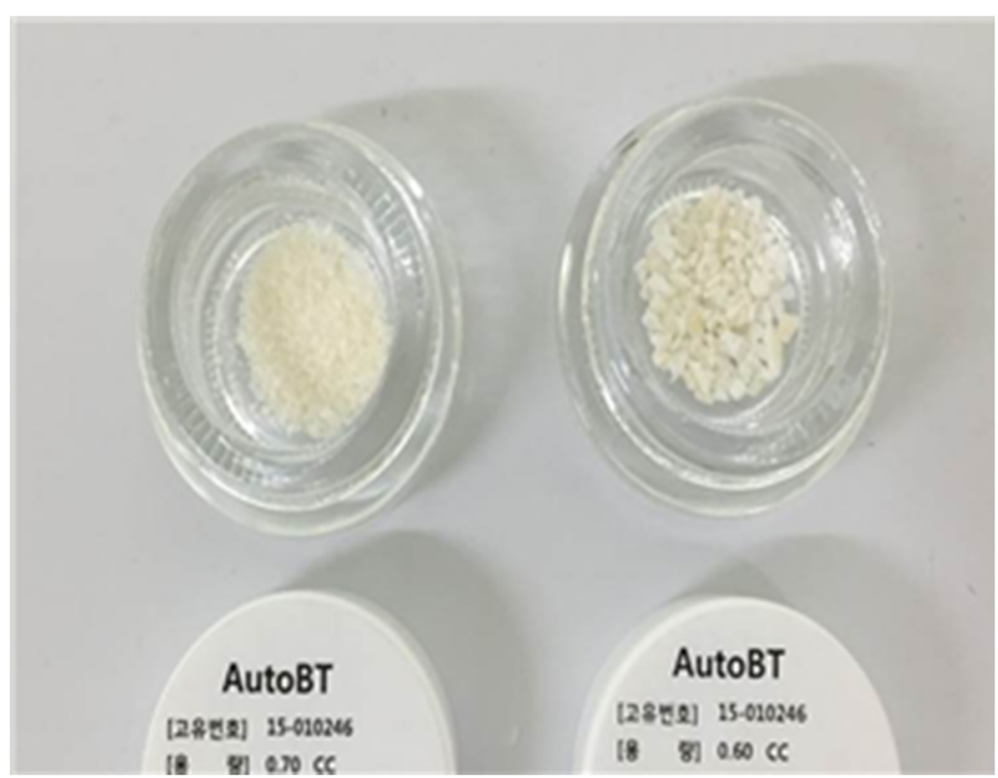

Fig. 1 Human demineralized dentin matrix $(0.25 \sim 1.0 \mathrm{~mm}, 1.0 \sim 2.0 \mathrm{~mm})$

supraorbital region, with care taken not to damage the periosteum. Then, two circular defects, $8 \mathrm{~mm}$ in diameter, were created on each side of the skull using a trephine bur, avoiding the nasofrontal suture of the exposed skull so as not to damage the endocranium. A total of four defects were grafted with DDM of different particle sizes and densities (Fig. 2), as follows: $0.1 \mathrm{~mL}$ of 0.25 - to 1.0 $\mathrm{mm}$ particles (group 1); $0.2 \mathrm{~mL}$ of 0.25 - to $1.0-\mathrm{mm}$ particles (group 2); $0.1 \mathrm{~mL}$ of 1.0- to 2.0-mm particles (group 3 ); and $0.2 \mathrm{~mL}$ of 1.0 - to 2.0 -mm particles (group 4).

The periosteum was sutured with 4-0 Vicryl and the dermis with 3-0 nylon suture. From the day of the operation until day 7 , antibiotic ointment was applied on the wounds and gentamicin was injected into the muscles to control infection.

\section{Production and observation of tissue specimens}

The three rabbits were sacrificed after 2, 4, and 8 weeks at each sacrifice. The defects were immediately grafted with DDM, and adjacent tissues were collected and fixed in $10 \%$ buffered formalin for more than 10 days. After the specimens were decalcified using Regular cal solution (6085, BBC Biochemical, Mount Vernon, WA, USA), samples $3 \mu \mathrm{m}$ in thickness were produced via ethanol dehydration and were embedded in paraffin and stained with hematoxylin-eosin and Masson's trichrome stains. Digital images were taken using a Panoramic MIDI Scanner (3DHISTECH, Budapest, Hungary).

\section{Optical microscopic observation}

Tissue samples were observed under an optical microscope (Olympus CX41, Olympus, Tokyo, Japan). Proliferation and

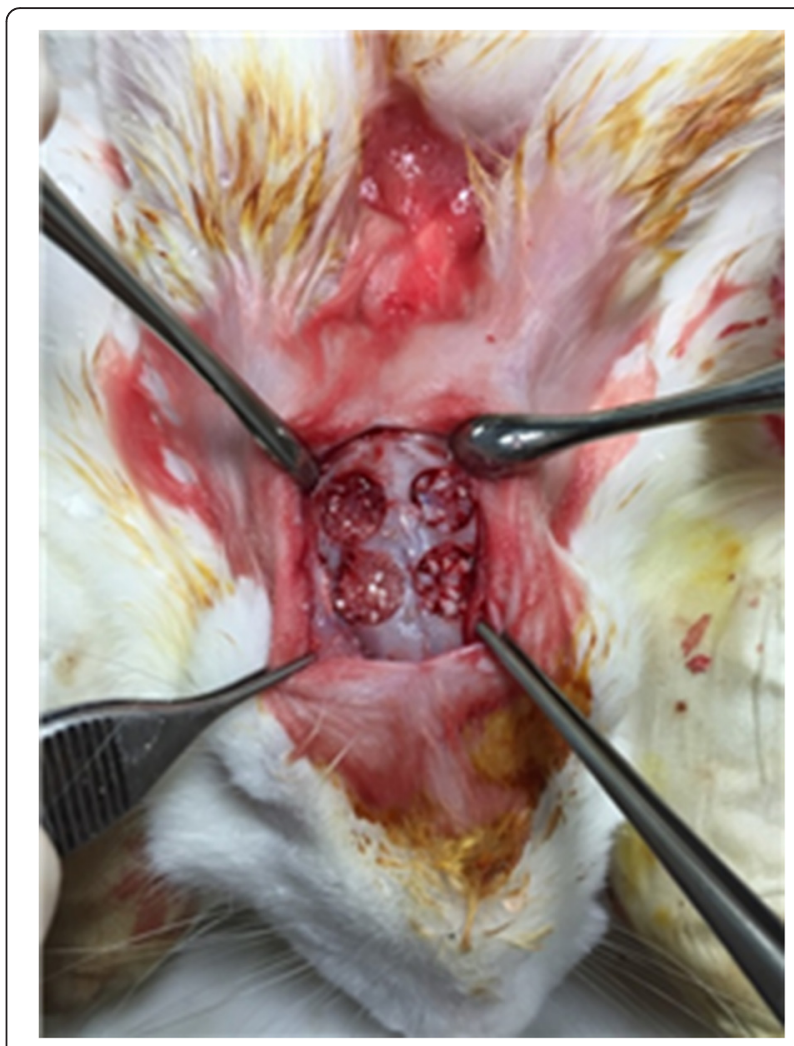

Fig. 2 Each group on rabbit calvaria 
inflammation of the connective tissues that had formed in space between the bone and graft materials were evaluated, as was evidence of fusion and osteogenesis. The external parts of the bone defects were not examined, because new bone formation in those cranial areas where normal bone tissues are present had little relation to the transplant materials.

\section{Histomorphometric analysis}

Digital images were acquired with the Panoramic MIDI Scanner. Specimens were magnified by 100 times to evaluate areas of newly formed bone. After creating a border along the defect and normal bone areas, the region containing newly formed bony tissues was converted into a percentage in which the defect area was regarded as 100 .

\section{Measurement of interparticle distance of graft materials} Digital images were obtained with the Panoramic MIDI Scanner, and the closest interparticle distances for each type of graft material were measured in all samples.

\section{Reverse transcription polymerase chain reaction (RT-PCR)} Total RNA was extracted from each frozen tissue using the RNeasy Mini Kit (QIAGEN, Hilden, Germany), and the extracted RNA was put into a Transcriptor First Strand cDNA Synthesis Kit (Roche diagnostic, Seoul, Korea), which synthesizes $20 \mu \mathrm{L}$ of complementary DNA (cDNA) from $250 \mathrm{ng}$ of RNA. A total volume of $20 \mu \mathrm{L}$, which included $2 \mu \mathrm{L}$ of cDNA and $1 \mu \mathrm{L}$ of $10 \mu \mathrm{M}$ F/R primer, was added to Maxime PCR PreMix (i-StarTaq, Intronbiotechnology, Seongnam, Korea). As for PCR conditions (Table 1), the gene expressions of osteonectin and osteopontin were analyzed, with GAPDH used as a housekeeping gene. Information about GAPDH and the primer sequences of osteonectin and osteopontin is shown in Tables 2 and 3.

\section{Statistical analysis}

Statistical analysis was performed using SPSS version 18 (SPSS, Chicago, IL, USA). The repeated measure ANOVA was conducted to compare new bone formation in each group on histomorphometric analysis. The statistical significance level was $p<0.05$.

Table 1 PCR sequence

\begin{tabular}{lll}
\hline Cycle & Temperature $\left({ }^{\circ} \mathrm{C}\right)$ & Time \\
\hline 1 & 95 & $5 \mathrm{~min}$ \\
30 & 94 & $15 \mathrm{~s}$ \\
& 60 & $15 \mathrm{~s}$ \\
& 72 & $30 \mathrm{~s}$ \\
1 & 72 & $10 \mathrm{~min}$ \\
1 & 4 & $\infty$ \\
\hline
\end{tabular}

Table 2 Osteonectin and osteopontin primer sequence

\begin{tabular}{ll}
\hline Primer & Sequence \\
\hline Osteonectin F & CTCCACCTGGACTACATCG \\
Osteonectin R & GCTGGCCAAACTGCCAGTG \\
Osteopontin F & GCTCAGCACCTGAATGTACC \\
Osteopontin R & CTTCGGCTCGATGGCTAGC \\
\hline
\end{tabular}

\section{Results}

\section{Histology}

At first, we examined the representative histology of each group of specimens. At 2 weeks, group 1 exhibited multinucleated giant cells, infiltrated lymphocytes, eosinocytes, macrophages, and a slight proliferation of connective tissue along the polygonal bone graft materials. Sites where existing bone tissue and bone graft materials were bound together could be seen in some areas. However, new bone formation was not observed (Fig. 3a, b). Group 2 showed an inflammatory response, with eosinocytes, lymphocytes, and macrophages surrounding bone graft materials, as well as proliferating connective tissue, and some areas contained existing bone tissue bound to bone graft materials (Fig. 3c, d). Group 3 showed a severe inflammatory response, the area being infiltrated with macrophages, lymphocytes, and eosinocytes, and bleeding was observed surrounding the bone graft materials. In some cases, multinucleated giant cells were noted as were the proliferation of connective tissue and inflammation between the materials (Fig. 3e, f). Similarly, group 4 showed an inflammatory response, with eosinocytes, lymphocytes, and macrophages surrounding the bone graft materials, and there was a noticeable proliferation of connective tissue. Although the new bone had formed from the existing bone, it had not formed between the materials (Fig. 3g, h).

At 4 weeks, lymphocytes and a few macrophages had infiltrated the materials in group 1 . The proliferating dense connective tissue showed a noticeable increase in fibroblasts, and in some areas, the fibroblasts had been transformed into osteoblasts and formed osteoid for new bone growth. Binding between existing bone tissue and bone graft materials was easily detected, and the new bone had appeared between the bone graft materials (Fig. 4a, b). In group 2, lymphocytes, macrophages, and a few multinucleated giant cells had infiltrated the materials, and there was a noticeable increase in connective tissue, which was dense in some parts, with a small amount of bone tissue between the connective tissue and the materials. However, there was no binding between the new bone generated

Table 3 GAPDH (NM_001082253.1) primer

\begin{tabular}{lll}
\hline Primer & Length & Sequence \\
\hline GAPDH F & 18 & CACCCAGAAGACCGTGGA \\
GAPDH R & 18 & GTCAGCTCGGGGATGAC \\
\hline
\end{tabular}




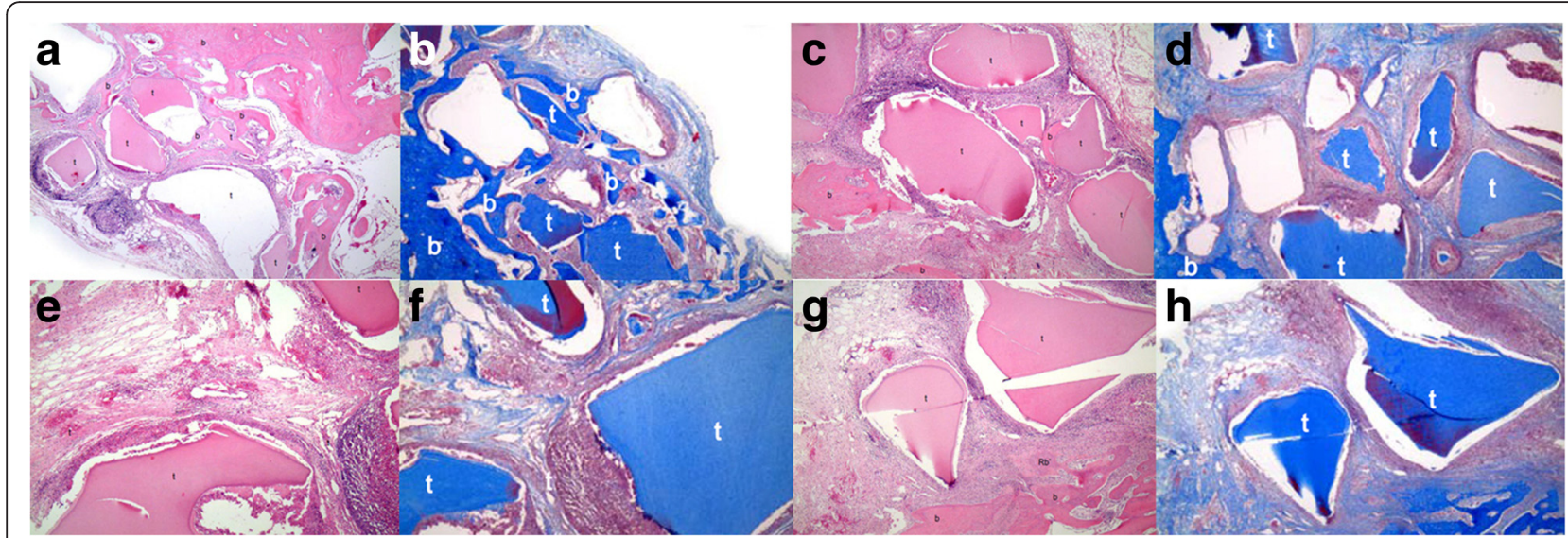

Fig. 3 The histological examination. a Histologic finding of group 1 after 2 weeks (H-E stain, $\times 40): t$ DDM, $b$ bone of skull, rb regenerative bony tissue, $R b$ regenerative bony tissue from the skull bone. $\mathbf{b}$ Histologic finding of group 1 after 2 weeks (M-T stain, $\times 40)$. $\mathbf{c}$ Histologic finding of group 2 after 2 weeks (H-E stain, $\times 40$ ). $\mathbf{d}$ Histologic finding of group 2 after 2 weeks (M-T stain, $\times 40$ ). e Histologic finding of group 3 after 2 weeks (H-E stain, X40). $\mathbf{f}$ Histologic finding of group 3 after 2 weeks (M-T stain, $\times 40$ ). $\mathbf{g}$ Histologic finding of group 4 after 2 weeks (H-E stain, $\times 40$ ). $\mathbf{h}$ Histologic finding of group 4 after 2 weeks (M-T stain, $\times 40$ )

from existing bone and the materials (Fig. 4c, d). Group 3 showed lymphocytes, macrophages, and a few multinucleated giant cells infiltrated among the materials. Fibrous tissue had increased slightly, but there was no binding between the new bone generated from the existing bone and the materials (Fig. 4e, f). In group 4, lymphocytes and macrophages had infiltrated the materials, and there was a slight increase in fibrous tissue, with no new bone formation between the materials; however, the bone tissue and the materials showed some binding (Fig. 4g, h).

At 8 weeks, group 1 showed infiltration of the materials by lymphocytes, macrophages, a few plasma cells and eosinocytes, and some multinucleated giant cells. Dense connective tissue had formed between the bone graft materials, and close to these materials, where fibrin was dense, osteoblasts, which had become differentiated from fibroblasts and had formed osteoid and then new bones (Fig. 5a, b). Group 2 showed less inflammation at 8 weeks than at 4 weeks, including macrophages, multinucleated giant cells, and lymphocytes, and denser connective tissue was found between the materials. Still, there was no binding between the new bone generated from the existing bone and the bone graft materials (Fig. 5c, d). Group 3 showed a slight inflammatory response, with macrophages, lymphocytes, and eosinocytes visible among the materials, in addition to noticeable dense connective tissue. The new bone was found between the materials, and activated osteoblasts could be seen within the bone tissue; however, the bone tissue was presumed to have formed from the existing bone (Fig. 5e, f). Group 4 showed a slight inflammatory

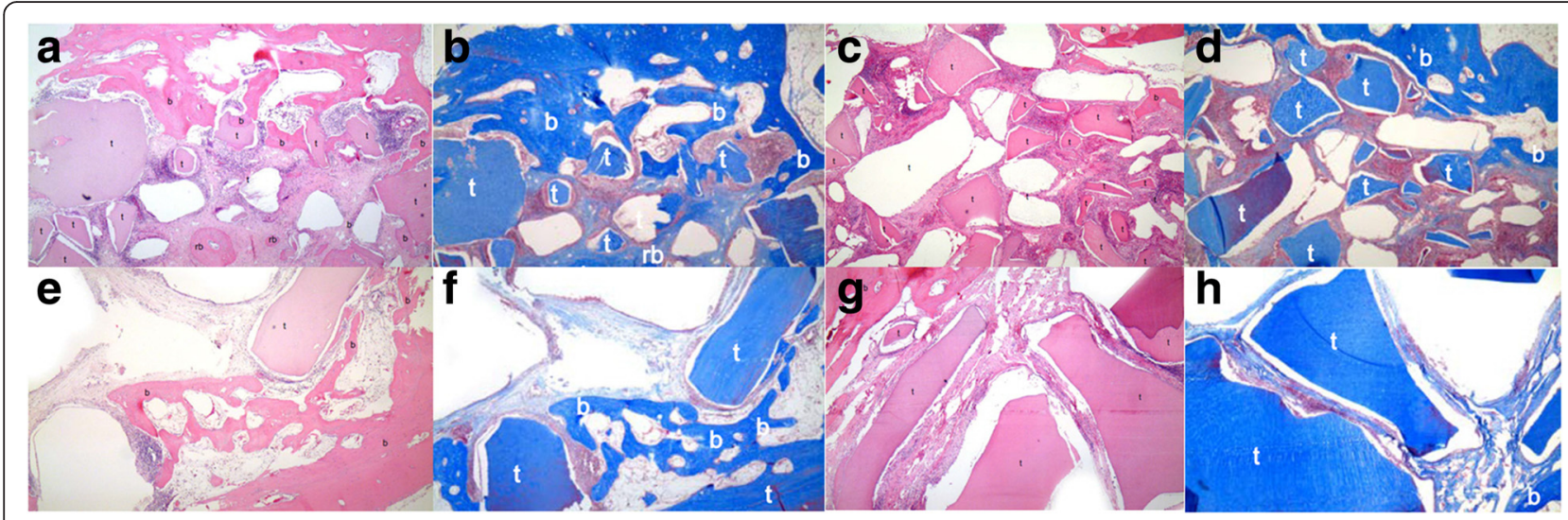

Fig. 4 The histological examination. a Histologic finding of group 1 after 4 weeks (H-E stain, $\times 40)$. b Histologic finding of group 1 after 4 weeks (M-T stain, $\times 40)$. c Histologic finding of group 2 after 4 weeks (H-E stain, $\times 40)$. d Histologic finding of group 2 after 4 weeks (M-T stain, $\times 40)$. e Histologic finding of group 3 after 4 weeks (H-E stain, $\times 40)$. $\mathbf{f}$ Histologic finding of group 3 after 4 weeks (M-T stain, $\times 40)$. $\mathbf{g}$ Histologic finding of group 4 after 4 weeks (H-E stain, $\times 40)$. $\mathbf{h}$ Histologic finding of group 4 after 4 weeks $(M-T$ stain, $\times 40)$ 


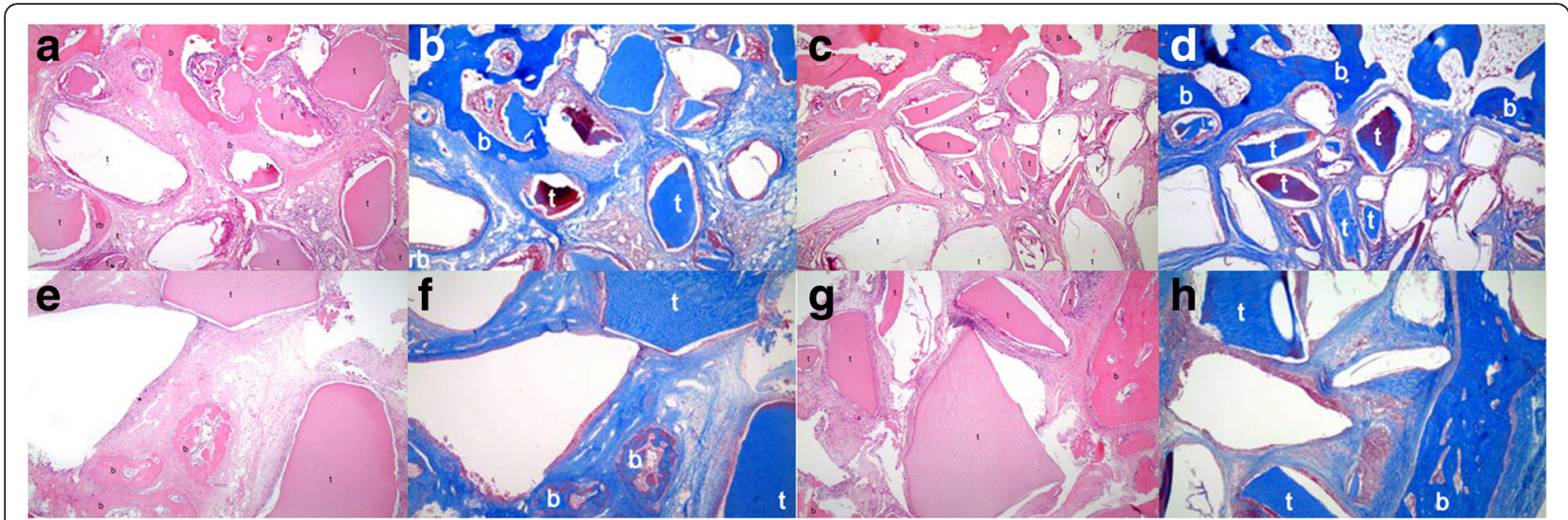

Fig. 5 The histological examination. a Histologic finding of group 1 after 8 weeks (H-E stain, $\times 40$ ). b Histologic finding of group 1 after 8 weeks (M-T stain, $\times 40)$. c Histologic finding of group 2 after 8 weeks (H-E stain, $\times 40)$. $\mathbf{d}$ Histologic finding of group 2 after 8 weeks (M-T stain, $\times 40)$. e Histologic finding of group 3 after 8 weeks ( $\mathrm{H}$-E stain, $\times 40$ ). $\mathbf{f}$ Histologic finding of group 3 after 8 weeks (M-T stain, $\times 40)$. $\mathbf{g}$ Histologic finding of group 4 after 8 weeks (H-E stain, $\times 40)$. $\mathbf{h}$ Histologic finding of group 4 after 8 weeks (M-T stain, $\times 40$ )

response, with macrophages, lymphocytes, and eosinocytes present among the materials, and there was a more noticeable increase in connective tissue; however, new bone formation between the materials was not observed (Fig. 5g, h).

\section{Histomorphometric analysis}

The percentages of the new bone that had formed in the rabbit skull defects at 2, 4, and 8 weeks, respectively, were $29.53 \pm 7.65 \%, 36.31 \pm 9.80 \%$, and $52.27 \pm 4.44 \%$ in group $1 ; 27.02 \pm 15.46 \%, 34.54 \pm 14.51 \%$, and $49.02 \pm$ $6.75 \%$ in group 2; $23.24 \pm 8.95 \%, 35.58 \pm 5.59 \%$, and $46.99 \pm 8.15 \%$ in group 3 ; and $23.98 \pm 5.56 \%, 34.43 \pm$ $12.87 \%$, and $44.96 \pm 6.41 \%$ in group 4. Although the results of these experiments at 2, 4, and 8 weeks all showed higher percentages of new bone formation in group 1 ( $0.1 \mathrm{~mL}$ of 0.25 - to $1.0-\mathrm{mm}$ particles), the differences compared with the other three groups were not statistically significant $(p>0.05)$ (Table 4$)$.

\section{Measuring the distance between materials}

These distances were $209.06 \pm 161.25 \mu \mathrm{m}$ for group 1 , $126.84 \pm 79.19 \mu \mathrm{m}$ for group 2, $880.42 \pm 579.63 \mu \mathrm{m}$ for group 3, and $299.42 \pm 153.52 \mu \mathrm{m}$ for group 4 (Table 5).

\section{RT-PCR analysis}

At 2 weeks, the expression of osteonectin was similar in all four groups of specimens. At 4 weeks, group 3 showed

Table 4 New bone formation (\%)

\begin{tabular}{llll}
\hline & 2 weeks & 4 weeks & 8 weeks \\
\hline Group 1 & $29.53 \pm 7.65$ & $36.31 \pm 9.80$ & $52.27 \pm 4.44$ \\
Group 2 & $27.02 \pm 15.46$ & $34.54 \pm 14.51$ & $49.02 \pm 6.75$ \\
Group 3 & $23.24 \pm 8.95$ & $35.58 \pm 5.59$ & $46.99 \pm 8.15$ \\
Group 4 & $23.98 \pm 5.65$ & $34.43 \pm 12.87$ & $44.96 \pm 6.41$ \\
\hline
\end{tabular}

slightly greater osteonectin expression, and at 8 weeks, group 1 showed greater expression (Fig. 6). On the analysis of osteopontin expression, there was little difference between each of the three periods, but after 2 weeks, expression of osteopontin was similar to that of osteonectin. Osteopontin expression was increased in group 3 at 4 weeks and in group 1 at 8 weeks (Fig. 7).

\section{Discussion}

Bone grafting is apparently used often in the oral and maxillofacial area to enhance aesthetic and functional recovery, stabilization, and healing. The basic objective of such grafting is to maintain the biomechanical role of bone by restoring its morphology and physiological function.

Bone graft materials are known to form bones in three ways. First, in osteogenesis, viable osteoblasts and preosteoblasts in the materials induce an ossification reaction around the graft sites to form new bone tissue. The amount of newly formed bones is proportionate to that of living graft cells. Osteogenesis is usually seen in cancellous bones and after bone marrow transplantation. A second process for creating new bone is osteoinduction. Chemotactic materials such as BMP induce the growth of undifferentiated mesenchymal cells around the graft site, and these cells are converted into chondroblasts and osteoblasts to form new bones. Third, through a process of osteoconduction, the bone graft materials function simply as a scaffold that enables vascularization of the site, and the differentiated mesenchymal cells around the site provide the chondroblasts and osteoblasts needed to form the new

Table 5 Particle distance ( $\mu \mathrm{m})$

\begin{tabular}{ccccc}
\hline & Group 1 & Group 2 & Group 3 & Group 4 \\
\hline Distance & 209.06 & 126.84 & 880.42 & 299.42 \\
& \pm 161.25 & \pm 79.19 & \pm 579.63 & \pm 153.52 \\
\hline
\end{tabular}




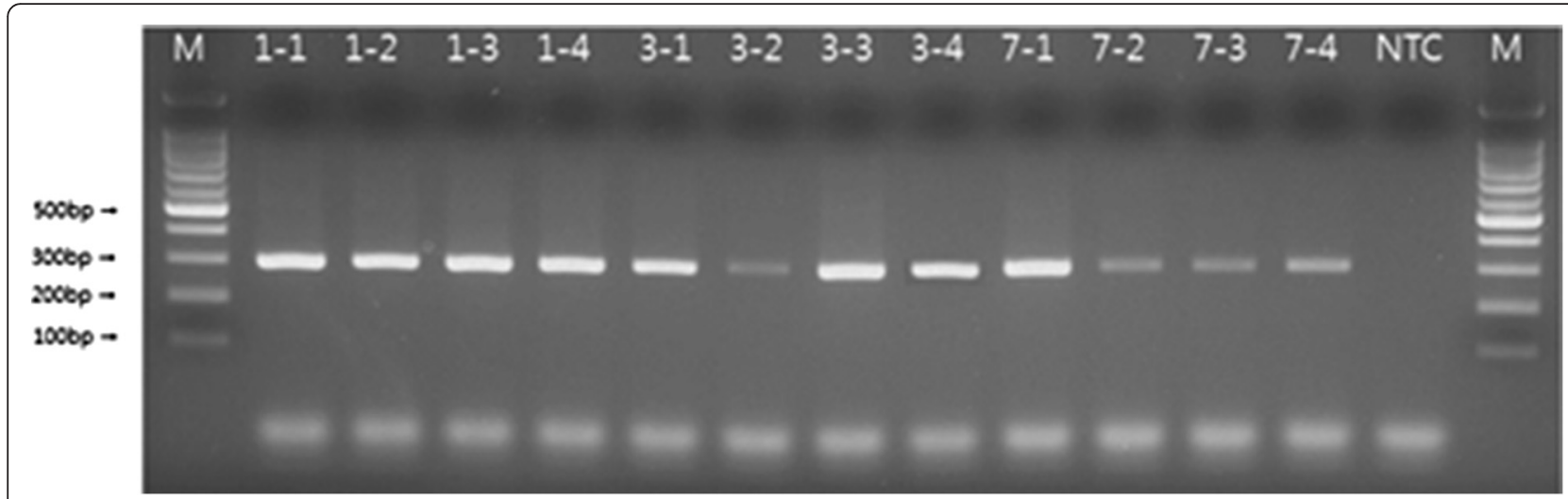

Fig. 6 RT-PCR (osteonectin). M size marker, NTC no template control

bone using grafting materials. New bones are formed by means of creeping substitution, which refers to the resorption of the graft materials along with the deposition of the new bone. The presence of the bone around the graft site and of differentiated mesenchymal cells is essential for osteoconduction [29-31].

The key ingredient in bone grafting subsequent to implant surgery is bone remodeling in order to withstand the occlusal load. Bone remodeling continuously proceeds through the delicate regulation of two contrasting procedures: bone resorption by osteoclasts and bone formation by osteoblasts. Bone tissue formed with the help of bone graft materials is dynamic, having the enhanced regenerative ability to continue to undergo remodeling according to the internal or external conditions.

Many studies have altered bone graft materials in attempts to improve the reactions of the bone. Among them have been reports indicating that bone graft materials with different particle sizes exhibit different bone-healing abilities [16-19]. Although still controversial, these results suggest that the smaller the particle size of the material, the greater the formation of bone. The reasons for this are said to be that smaller particles increase the available surface area, and more growth factors of various kinds are secreted to facilitate the formation of new blood vessels and accelerate the differentiation of mesenchymal cells into osteoblasts, thus assisting the process of bone formation.

In addition, it has been reported that the spaces between particles should be more than $100 \mu \mathrm{m}$ in order to achieve proper vascularization and bone formation [32, 33]. According to some researchers, spaces of 300 to $500 \mu \mathrm{m}$ between particles led to greater formation of bone as compared with spaces of 50 to $100 \mu \mathrm{m}[34,35]$. In this context, in bone formation experiments using hydroxyapatite, an interconnected porous structure between particles was found to be a significant factor in osteoconduction and synostosis [36, 37]. Thus, both a porous structure and particle size are critical factors in that they enhance boneforming ability and affect the period of resorption.

Previous reports indicated an association between the particle size of bone grafting materials and the success of bone formation, and particles that are 0.25 to $1.0 \mathrm{~mm}$ and 1 to $2 \mathrm{~mm}$ in size are available on the domestic market. The DDM used in our study was also manufactured in these sizes, and both the porous structure and space between the bone grafting materials were considered to

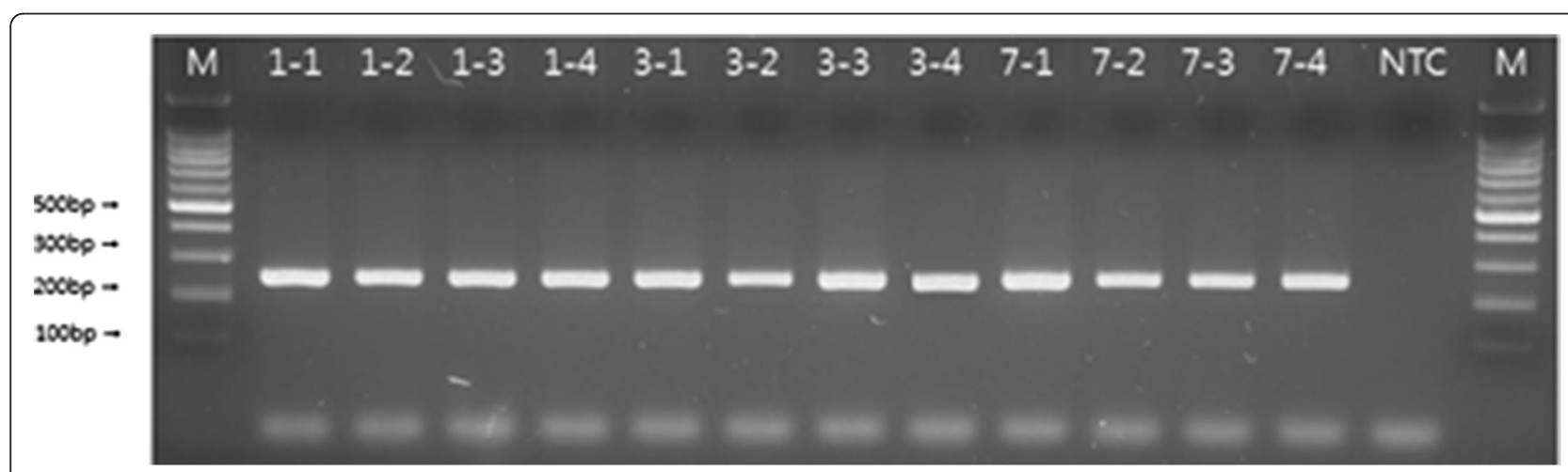

Fig. 7 RT-PCR (osteopontin) 
affect the ability of bone formation. Therefore, in this study, we tested materials of different densities to evaluate the effects of different distances between the bone graft materials. As a result, we found that particles 0.25 to $1.0 \mathrm{~mm}$ in size and spaces of $200 \mu \mathrm{m}$ between the materials activated bone formation the most.

Owing to the considerable inflammatory response and lack of bone formation observed in the early stages after grafting, we believe that the use of human DDM in the animal model should be regarded not as autologous but as heterologous tissue grafting.

As analyzed on RT-PCR, osteonectin has been found in various kinds of cells, but when detected in adult cells, it has appeared only in calcified tissues. Previously, osteonectin was believed to have an affinity to bind to apatite and collagen type 1 that temporarily accelerates skeletal calcification. However, SPARC, or osteonectin/BM-40 (secreted protein acidic and rich in cysteine), is from the basement membrane and contains the same amino acid sequences as osteonectin, so the role of osteonectin in calcification is now regarded negatively. Osteopontin is a phosphoprotein that constitutes the framework. It contains sialic acid and is referred as sialoprotein-1 (BSP-1). Its high-binding affinity with calcium offers an explanation for the formation of calcified tissues or modeling. Protein from osteopontin has several calcium binding sites and such binding converts it to a three-dimensional structure that is related to certain functions. In the present study, the concentrations of osteonectin and osteopontin were elevated until the eight week, indicating the active formation of bone.

\section{Conclusions}

In conclusion, we found that small particles of bone grafting material measuring 0.25 to $1.0 \mathrm{~mm}$ with $200 \mu \mathrm{m}$ of space between the materials were effective in promoting osteogenesis. In our study, the space between the bone graft materials was considered to be two-dimensional and was measured accordingly. Thus, future studies should consider a three-dimensional evaluation of the space as well as other options for determining the amount of materials needed for successful bone formation.

\section{Competing interests}

The authors declare that they have no competing interests.

\section{Authors' contributions}

JWN collected the data and wrote the manuscript. MYK helped in the data collection. SJH reviewed the manuscript. All authors read and approved the final manuscript.

\section{Acknowledgements}

None.

Received: 19 April 2016 Accepted: 20 June 2016 Published online: 05 July 2016

\section{References}

1. Boyne PJ (1973) Induction of bone repair by various bone grafting materials, hard tissue growth, repair and remineralization. Ciba Found Symp 11:121-128

2. Masters DH (1988) Implants, bone and bone substitutes. Calif Dent Asso J 16:56-65

3. Jarcho M (1981) Calcium phosphate ceramics as hard tissue prosthetics. Clin Orthop 157:259-278

4. Arrington ED, Smith WJ, Chambers HG, Bucknell AL, Davino NA (1996) Complications of iliac crest bone graft harvesting. Clin Orthop Relat Res 329:300-309

5. Goulet JA, Senunas LE, DeSilva GL, Greenfield ML (1997) Autogenous iliac crest bone graft: complications and functional assessment. Clin Orthop Relat Res 339:76-81

6. Lane JM (1995) Bone graft substitutes. West J Med 163:565-566

7. Hislop WD, Finlay PM, Moos KF (1993) A preliminary study into the uses of anorganic bone in oral and maxillofacial surgery. Br J Oral Maxillofac Surg 31:149-153

8. Buring K, Urist MR (1967) Effects of ionizing radiation on the bone induction principle in the matrix of bone implants. Clin Orthop 44:225-234

9. Mellonig JT, Prewett AB, Moyer MP (1992) HIV inactivation in a bone allograft. J Periodontol 63:979-983

10. Jarcho M (1986) Biomaterial aspects of calcium phosphate. Dent Clin N Am 30:25-47

11. Kim SY, Kim SG, Lim SC, Bae CS (2004) Effects on bone formation in ovariectomized rats after implantation of tooth ash and plaster of Paris mixture. J Oral Maxillofac Surg 62:852-857

12. Kim YK, Lee JH, Kim KY, Um IW, Murata M, Ito K (2013) Analysis of organic components and osteoinductivity in autogenous tooth bone graft material. Maxillofac Plast Reconstr Surg 35:353-359

13. Kim YK, Lee HJ, Kim KY, Kim SG, Um IW (2011) Guide bone regeneration using autogenous teeth: case reports. J Korean Assoc Oral Maxillofac Surg 37:142-147

14. Kim SG, Chung CH, Kim YK, Park JC, Lim SC (2002) The use of particulate dentinplaster of Paris combination with/without plate-rich plasma in the treatment of bone defects around implants. Int J Oral Maxillofac Implants 17:86-94

15. Lynch SEMR, Nevins M, Wisner-Lynch LA (2008) Tissue engineering: applications in maxillofacial surgery and periodontics, 2nd edn. Quintessence, Chicago

16. Shirota T, Ohno K, Motohashi M, Mishi K (1996) Histologic and microradiologic comparison of block and particulate cancellous bone and marrow grafts in reconstructed mandibles being considered for dental implant placement. Oral Maxillofac Surg 54:15-20

17. Isaksson S, Alberius P, Klinge B, Jonsson J (1992) Contribution of autogenic membranous bone chips and bone paste to healing of rabbit skull defects. Scand J Dent Res 100:274-278

18. Fonseca RJ, Clark PJ, Burker EJ, Baker RD (1980) Revascularization and healing of onlay particulate autologous bone grafts in primates. J Oral Maxillofac Surg 38:572-577

19. Melloning JT, Levey R (1984) The effect of different sizes of freeze dried bone allograft on bone growth. J Dent Res 63:222

20. Robinson E (1969) Osseous coagulum for bone induction. J Periodontol 40: 503-510

21. Rivault AF, Toto PD, Levy S, Gargiulo AW (1971) Autogenous bone grafts: osseous coagulum and osseous retrograde procedures in primates. J Periodontol 42:787-796

22. Shapoff CA, Bowers GM, Levy B, Mellonig JT, Yukna RA (1980) The effect of particle size on the osteogenic activity of composite grafts of allogenic freeze-dried bone and autogenous marrow. J Periodontol 51:625-630

23. Pallesen L, Schou S, Aaboe M, Hjorting-Hansen E, Nattestad A, Melsen F (2002) Influence of particle size of autogenous bone grafts on the early stage of bone regeneration. A histologic and stereologic study in rabbit calvarium. Int J Oral Maxillofac Implants 17:498-506

24. Hall EE, Meffert RM, Hermann JS, Mellonig JT, Cochran DL (1999) Comparison of bioactive glass to DFDB in the treatment of intrabony defects around implants in the canine mandible. J Periodontol 70:526-535

25. Fucini SE, Quintero G, Gher ME, Black BS, Richardson AC (1993) Small versus large particles of DFDBs in human intrabony periodontal defects. J Periodontol 64:844-847

26. Urist MR, Silverman BF, Buring K, Dubuc FL, Rosenberg JM (1967) The bone induction principle. Clin Orthop Relat Res 53:243-283 
27. Kim KY, Yeo IS, Kim SG, Um IW (2011) Analysis of crystalline structure of autogenous tooth bone graft material: X-ray diffraction analysis. J Korean Assoc Oral Maxillofac Surg 37:142-147

28. Kim YK, Kim SG, Byeon JH, Lee HJ, Um IU, Lim SC et al (2010) Development of a novel bone grafting material using autogenous teeth. Oral Surg Oral Med Oral Pathol Oral Radiol Endod 109:496-503

29. Glowacki J, Mulliken JB (1980) Induced osteogenesis for repair and construction in the craniofacial region. Plast Reconstr Surg 65:553-560

30. Yim CJ (1998) Oral and maxillofacial reconstruction with bone allograft. Maxillofac Plast Reconstr Surg 56:706-714

31. Glowacki J, Mulliken JB (1985) Demineralized implants. Clin Plast Surg 12:233-241

32. Klawitter JJ, Hulbert SF (1971) Application of porous ceramics for the attachment of load bearing internal orthopedic application. J Biomed Master Res Sympos 2:161

33. Pederson KN, Haanaes HR, Lyng S (1974) Tissue ingrowth into mandibular intrabony porous ceramic implants. Int J Oral Surg 3:158

34. Chang BS, Lee CK, Hong KS (2000) Osteoconduction at porous hydroxyapatite with various pore configurations. Biomaterials 21:1291-1298

35. Flautre B, Descamps M, Delecourt C (2001) Porous HA ceramic for bone replacement: role of the pores and interconnections experimental study in the rabbit. J Mater Sci Mater Med 12:679-682

36. Akazawa T, Murata M, Sasaki T (2006) Biodegradation and bioabsorption innovation of the functionally graded bovine bone oriented apatite with blood permeability. J Biomed Mater Res 76:44-51

37. Tamai N, Myoui A, Tomita T (2002) Novel hydroxyapatite ceramics with an interconnetive porous structure exhibit superior osteoconduction in vivo. J Biomed Mater Res 59:110-117

\section{Submit your manuscript to a SpringerOpen ${ }^{\circ}$ journal and benefit from:}

- Convenient online submission

- Rigorous peer review

- Immediate publication on acceptance

- Open access: articles freely available online

- High visibility within the field

- Retaining the copyright to your article

Submit your next manuscript at $>$ springeropen.com 